\title{
Nehéz helyzetben a HEART Team: valve-in-valve implantáció?
}

\author{
Kracskó Bertalan1, Kertész Attila1, Vajda Gusztáv', Jenei Csaba1, Rácz lldikó1, \\ Szerafin Tamás², Szokol Miklós', Balogh Ágnes', Csanádi Zoltán', \\ Bódi Annamária ${ }^{1}$
}

\author{
Debreceni Egyetem ÁOK, ${ }^{1}$ Kardiológiai és Szívsebészeti Intézet, Kardiológiai Tanszék, \\ ${ }^{2}$ Kardiológiai és Szívsebészeti Intézet, Szívsebészeti Tanszék, Debrecen
}

Levelezési cím:

Dr. Kracskó Bertalan, 4032 Debrecen, Móricz Zs krt. 22. E-mail: kracsko.bertalan@med.unideb.hu

\begin{abstract}
Napjainkban a transzkatéteres aortabillentyű-beültetés (TAVI) alternatív megoldásként szerepel a magas mütéti rizikójú, aortabillentyü-betegséggel rendelkező betegek kezelésében.

2003-ban szignifikáns aortabillentyű-szűkület miatt 25 mm-es Stentless Pericarbon Freedom biológiai műbillentyű-beültetésen átesett 79 éves nőbeteg felvételét (2017. május 17.) megelőzően két héttel jelentkező visszatérő láz, valamint echokardiográfiával igazolódott újkeletű súlyos aortabillentyű-elégtelenség miatt irányították Klinikánkra. Hagyományos TEE során felmerült mobilis vegetáció lehetősége, azonban szívsebészeti konzíliumot követően elvégzett 3D TEE-vizsgálat a non-koronáriás tasak kifejezett mobilitását és súlyos aortabillentyű-elégtelenséget igazolt (vena contracta area: $1,2 \mathrm{~cm}^{2}$ ), egyértelmü vegetáció nélkül. A látott szívultrahangos kép alapján a HEART Team a billentyütasak ruptúráját valószínűsítette és tekintettel a beteg magas mütéti rizikójára két hét antibiotikum-kezelést követően valve-in-valve transzkatéteres mủbillentyű-implantációt javasolt, amely Klinikánkon sikeresen megtörtént. Hazabocsájtását megelőzően elvégzett kontroll transztorakális szívultrahangon jól müködő billentyű igazolódott.
\end{abstract}

Kulcsszavak: transzkatéteres aortabillentyű-implantáció, valve-in-valve, endocarditis, heart team döntés

HEART Team in trouble: valve-in-valve implantation?

In recent years, transcatheter aortic valve implantation (TAVI) gives the possibility to treat patients with significant aortic valve disease with high preoperative mortality risk.

On $17^{\text {th }}$ of May, 201779 years old female patient was referred to our Institute because of the possibility of biological valve (25 mm of Stentless Pericarbon Freedom in 2003) endocarditis after a two week observation in a local hospital where she was admitted with recurrent fever, cough and aortic regurgitation detected by echocardiography. A mobile vegetation, proved by traditional transoesophageal echocardiography, suggested artificial valve endocarditis. 3D TEE recordings have also raised the possibility of the rupture of non-coronary cusp. According to detailed analysis, the partial rupture of the non-coronary cusp was proven with severe aortic valve insufficiency (vena contracta area: $1.2 \mathrm{~cm}^{2}$ ) without vegetation. Regarding the high preoperative surgical risk, HEART Team decided to go through valve-in-valve TAVI, which was successfully performed. Before emission well-functioning valve was visualized by control echocardiography.

Keywords: transcatheter aortic valve impantation, valve-in-valve, endocarditis, heart team decision 


\section{Bevezetés}

Napjainkban a transzkatéteres aortabillentyü-beültetés (TAVI) alternatív megoldásként szerepel a magas mütéti rizikójú, aortabillentyü-betegséggel rendelkező betegek kezelésében. A magas mütéti rizikójú betegek egy külön csoportját képezik azok, akik a korábban beültetett biológiai mủbillentyű degenerálódása következtében kerülnek látótérbe. Ebben a csoportban is lehetőség van katéteres úton történő billentyűimplantációra valve-in-valve formában $(1,2)$.

\section{Esetismertetés}

79 éves nőbeteg anamnézisében hipertónia, illetve 2002-ben struma nodosa miatti aspirációs citológia szerepel (malignitást nem igazolt). 2000-ben derült fény degeneratív aortabillentyü-szükületére, amely miatt 2003 júliusában a debreceni Szívsebészeti Klinikán egy 25 mm-es Pericarbon Freedom típusú, „stentless” biológiai aortabillentyű-beültetés történt (1. ábra). Folyamatos kardiológiai kontrollok során mübillentyú-diszfunkció nem igazolódott, az utolsó tervezett kontroll echokardiográfiás vizsgálat 2016-ban az akkor panaszmentes betegnél jól működő mủbillentyűt igazolt a korábbiaknak megfelelő transzvalvuláris grádiensekkel (18 Hgmm-es átlaggrádiens és 33 Hgmm-es csúcsgrádiens), minimális mértékű, centrális helyzetű aortabillentyü-regurgitációval.

2017. május 3-án a beteg az egri Markhot Ferenc Kórház kardiológiai osztályára került felvételre visszatérő fulladás, láz, háti fájdalom, köhögés és sárgás köpetürítés miatt magasabb gyulladásos paraméterekkel: C-reaktív protein: 79,5 mg/l, fehérvérsejtszám: 7,2 G/l, balra

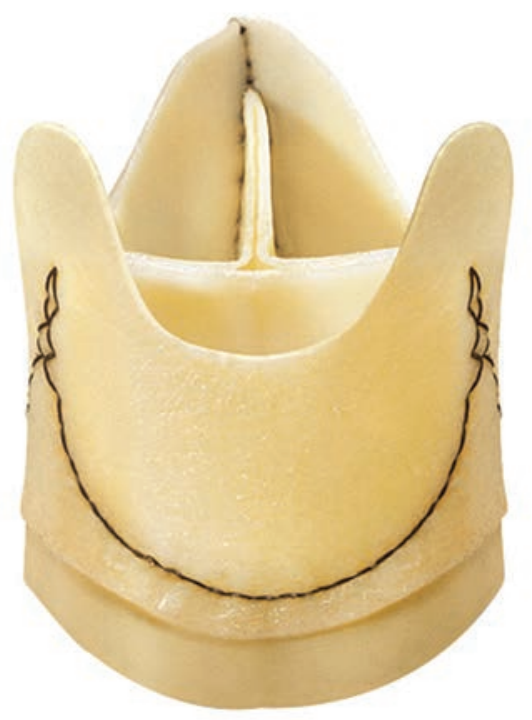

1. ÁBRA. Pericarbon Freedom Stentless aortamübillentyű szerkezete ex vivo (gyártó cég engedélyével megjelent ábra) tolt vérkép, hs troponin T: 403,3 ng/l. Mellkasröntgen mindkét oldalon két harántujjnyi pleurális folyadékot mutatott, valamint felvetette a jobb oldali bazális tüdőterületeket érintő tüdőgyulladás lehetőségét. Hemokultúrából kórokozó nem tenyészett ki. Empirikusan elindított parenterális levofloxacin terápia mellett tüdőgyulladása szanálódott, gyulladásos paraméterei normalizálódtak. Az antibiotikumot 10 nap után elhagyták. Transztorakális echokardiográfia (TTE) készült a biológiai múbillentyüre és lázas állapotra tekintettel, amely a korábbi értékekkel összevetve a billentyű feletti grádiens fokozódását és novumként súlyos aortabillentyű-elégtelenséget igazolt megtartott bal kamra szisztolés funkcióval (csúcsgrádiens: 49 Hgmm, átlaggrádiens: 25 Hgmm, $\mathrm{V}_{\max }$ : 3,5 m/sec, aortaregurgitáció mértéke: III-IV. fokú, nyomásfelezési idő: $153 \mathrm{msec}$, vena contracta: $7 \mathrm{~mm}$, bal kamra ejekciós frakció: 59\%).

Degenerálódott műbillentyű, illetve a klinikai előzmények felvetették endocarditis lehetőségét, amely miatt 2017. május 17-én a beteg Klinikánkra került, ekkor már láztalanul, NYHA II. funkcionális stádiumra jellemző panaszokkal. Fizikális vizsgálattal a kifejezett diasztolés zörej mellett érdemi eltérés nem volt észlelhető. Érkezési laborokban kismértékben emelkedett CRP-szint (15,7 mg/l) és a korábbról ismert enyhe fokú anémia (Hgb: 106 g/l), valamint beszükült vesefunkció (eGFR: $35 \mathrm{ml} /$ perc/1,73 $\mathrm{m}^{2}$ ) igazolódott magas NT-proBNP-szinttel (18859,11 ng/l). Ismételt TTE jó szisztolés balkamra-funkció mellett megerősítette a jelentős, III-IV. fokú aortabillentyűregurgitációt, illetve a billentyűn egy $3 \times 8 \mathrm{~mm}$-es mobilis képlet is ábrázolódott. Transoesophagealis echokardiográfia (TEE) egyértelmú endocarditist véleményezett degeneratív billentyűkárosodás mellett. $A$ felvételeken az aortabillentyű bal kamrai felszínén látott, a szívciklussal szinkron mozgó, kifejezetten mobilis vegetációnak imponáló képlet mérete ekkor $3 \times 10 \mathrm{~mm}$ volt. A folyamat paravalvularis terjedése, tályog, fisztula, álaneurizma nem igazolódott (2. ábra). Múbillentyű-endocarditisnek megfelelően kombinált, empirikus antibiotikum-kezelés indult. A még érkezéskor levett hemokultúra egy mintájából koaguláz negatív Staphylococcus tenyészett ki (Staphylococcus epidermidis), amelyet infektológiai konzílium kontaminációnak véleményezett. Szívsebészeti konzílium, habár TEE-vel az eset endocarditisnek tünt (a módosított Duke-féle kritérium alapján csupán lehetséges endocarditis diagnózisát merítette ki), felvetette a biológiai műbillentyűknél időnként előforduló hiba, a tasak részleges ruptúrájának lehetőségét, és a mütét előtt 3D TEE-vizsgálat elvégzését javasolta. A vizsgálat elkészültét követően a felvételek részletes elemzésével (3D „full volume” natív és színes Dopplerrel kombinált „multibeat” felvételek) a súlyos regurgitáció (vena contracta area: $1,2 \mathrm{~cm}^{2}$ ) valvuláris jellegén túl vegetáció nem látszott, azonban a non-koronáriás tasak túlzott mobilitása, illetve a kamrába történő prolapszusa alapján a tasak részleges ruptúrája volt valószínűsíthető a másik két tasak megfelelő mozgása mellett (3. ábra). 


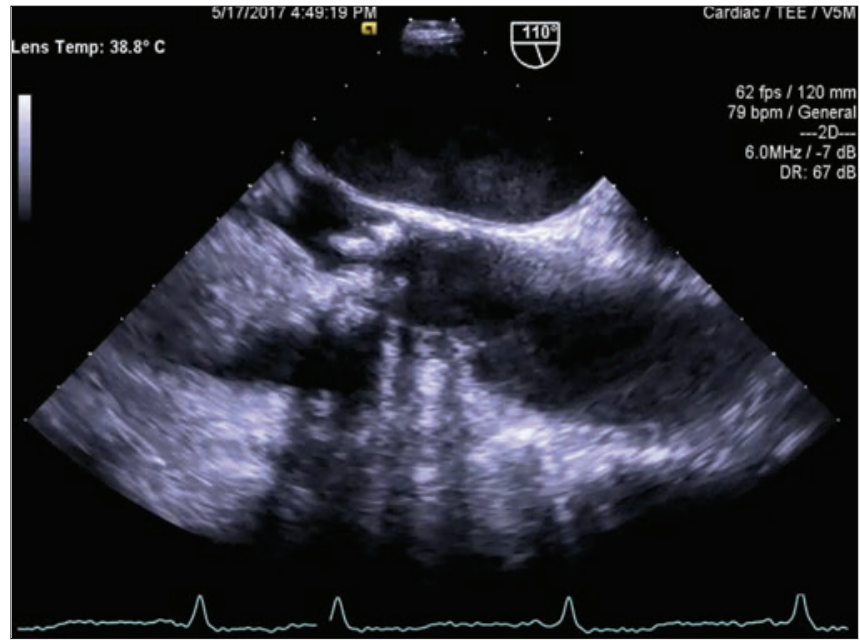

2. ÁBRA. Az első transoesophagealis echokardiográfia során (aortabillentyű felső oesophagealis hossztengelyi metszet, 110 fok) végdiasztoléban jól látható az aortabillentyű bal kamra felé eső oldalán elhelyezkedő vegetációnak imponáló képlet
Az adatok alapján (endocarditisre nem jellemző hemokultúra és TEE-vizsgálat) az aktív endocarditis kizárhatóvá vált, viszont a jelentős regurgitáció miatt mielőbbi megoldásra volt szükség. Ebben a speciális esetben két egymással szembenálló tényezőt kellett figyelembe venni: egyrészt kalkulálva a beteg mútéti rizikóját (magas életkor, veseelégtelenség, reoperáció - STS score: 7,07\%, EuroScore 2: 17,7\%), a nyitott szívmútét magas kockázatú; másrészt az Intézetünkben elvégzett katéteres billentyübeültetések néhány kivételtől eltekintve döntően az aortastenosis eseteire korlátozódnak. Esetünkben az aortabillentyű-regurgitáció billentyűstenosis nélküli minimálisan kalcifikált mübillentyű mellett alakult ki. Ezek mérlegelésével a HEART Team (kezelőorvos, szívsebész, invazív kardiológus, illetve 3D echokardiográfiában járatos szakember) az Európai Kardiológus Társaság ajánlásával egyetértésben (3) végül a TAVI-hoz szükséges vizsgálatok elvégzését (koronária-angiográfia, aortográfia és perifériás angiográfia, kontrasztanyagos CT-angiográfia [CTA]), és amennyiben az kivitelezhető, katéteres billentyüimplantációt javasolt.

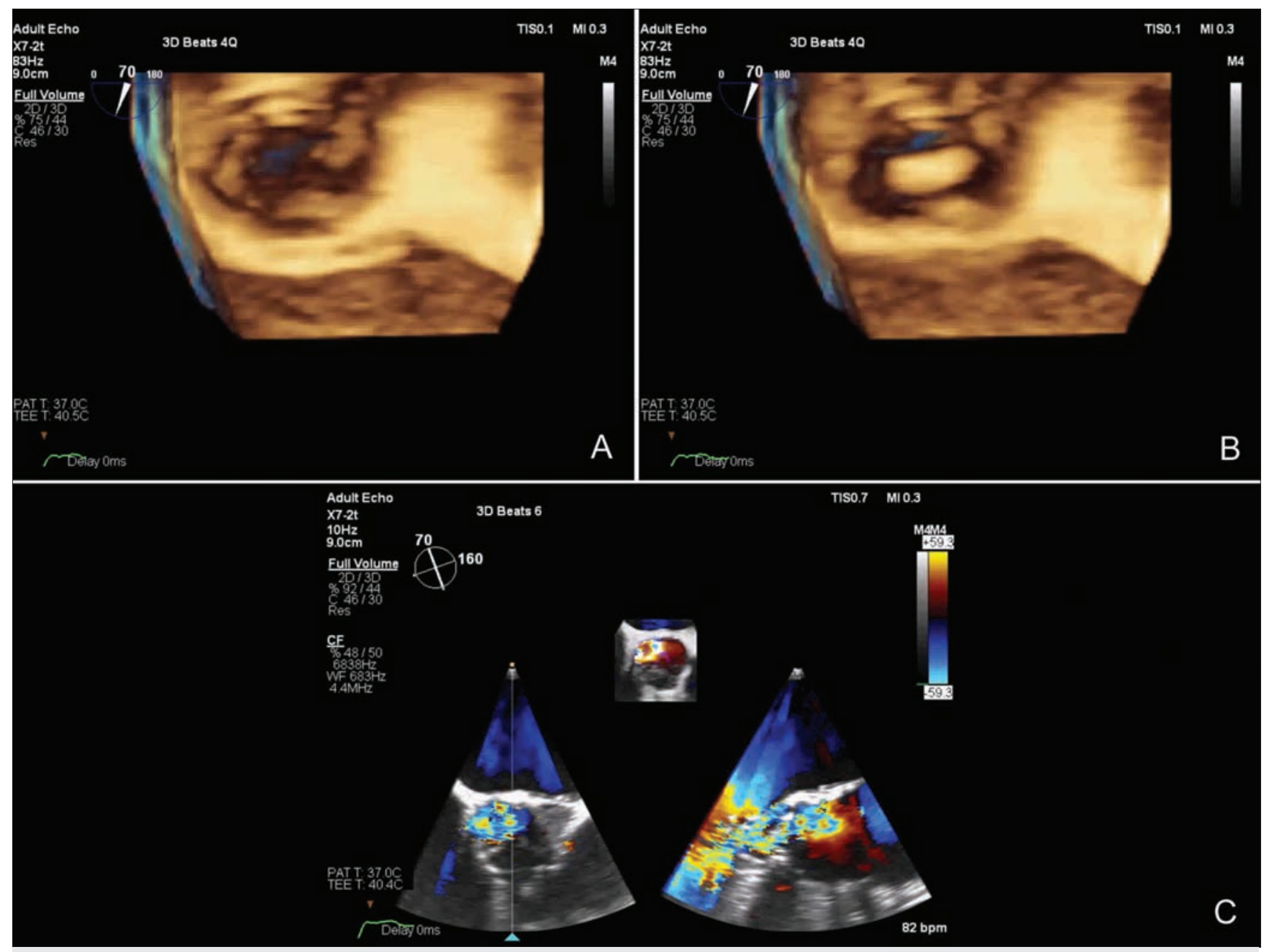

3. ÁBRA. 3 dimenziós echokardiográfia során a végszisztolés fázisban (A) érdemi áramlási akadály nem ábrázolódik a kiáramlási pálya felöl, végdiasztoléban (B) viszont jól látható a non-koronáriás tasak kiáramlási pályába történő prolapszusa. Színes Dopplerrel kiegészítve a jelentős regurgitáció helyzete szintén a non-koronáriás tasaknak megfelelő (C) 

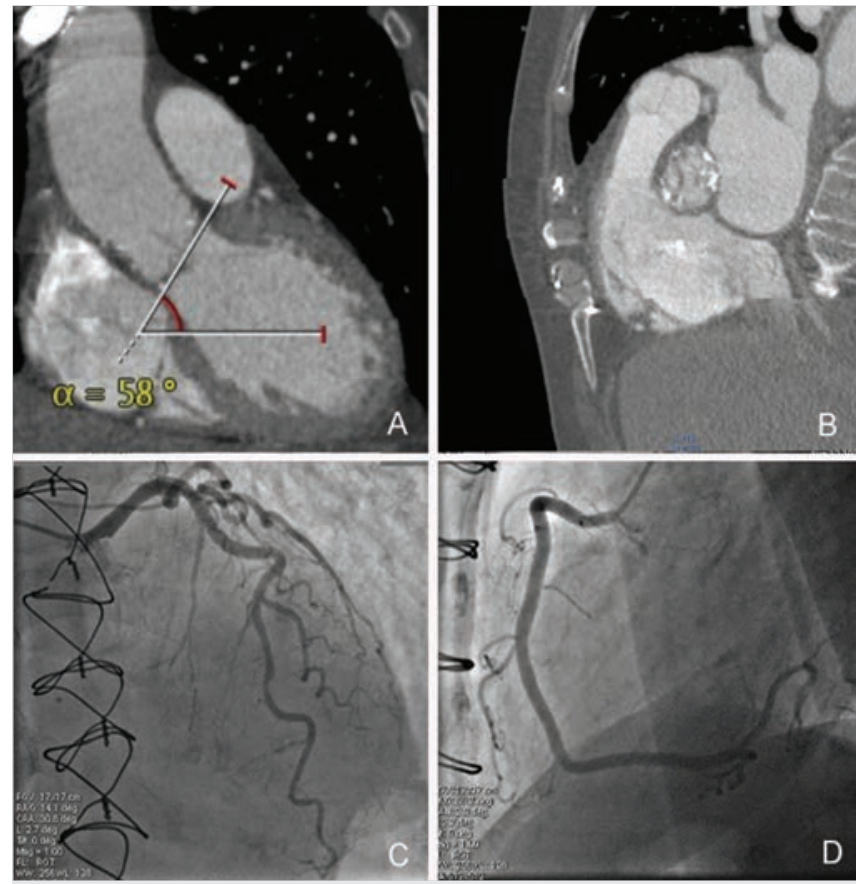

4. ÁBRA. A TAVI elvégzéséhez szükséges vizsgálatok alapján a transzkatéteres billentyübeültetés kivitelezhető volt: CTA-vizsgálattal implantációhoz megfelelő bal kamra-aorta szög igazolódott (A); jól látható a destruálódott billentyú szerkezete a CTA-n (B), koronária-angiográfia szignifikáns szűkületet nem mutatott (C, D)

Koronária-angiográfia során ép koronáriarendszer igazolódott, perifériás angiográfia és CTA alapján mindkét oldali femorális artéria megfelelőnek bizonyult a beavatkozás elvégzéséhez (4. ábra).
A kontrasztos CT-felvételek elemzése alapján a korábban beültetett billentyúbe egy $29 \mathrm{~mm}$-es Core Valve Evolute $\mathrm{R}$ implantációja tűnt megfelelőnek. A beavatkozás kapcsán a billentyű felvezetése a jobb oldali femorális artérián keresztül történt általános anesztézia mellett. A neoannulus síkja alatt több alkalommal történt billentyű nyitási kísérlet során azonban a billentyü többször is kipattant az aortagyökből. Végül a billentyü minimális paravalvularis regurgitáció mellett ideális pozícióba került, azonban az elengedést követően a bal kamra felé csúszott. Aortográfiás és TEE-ellenőrzést követően jelentős „upskirt” regurgitáció igazolódott, amely miatt egy második TAVI billentyűimplantáció történt (5. ábra). Ezt követően már érdemi paravalvuláris leak nem látszott, a második billentyű nem deformálódott, jelentős grádiens a kettős implantáció ellenére sem volt mérhető. A beteg keringése 4 napos intenzív osztályos megfigyelése alatt mindvégig stabil volt, láza nem ismétlődött, pacemaker-ingerlésre nem volt szükség. Az implantációt követő második napon emelkedő C-reaktív proteinszint miatt (91,1 $\mathrm{mg} / \mathrm{l})$ ismételten levett hemokultúrából kórokozó már nem tenyészett ki. Rövid ideig tartó ismételt antibiotikum-kezelés mellett CRP-értéke normalizálódott (9,5 mg/l). Kontroll TTE során megtartott bal kamra szisztolés funkció igazolódott szegmentális falmozgászavar nélkül. A billentyü felett jelentős grádienst nem mértünk (átlaggrádiens: 26 Hgmm, csúcsgrádiens: 38 Hgmm), aortabillentyűregurgitáció nem volt.

A közlemény írásának időpontjában a beteg jól van, láza nem ismétlődött, a kontroll kardiológiai vizsgálatokon a hazabocsájtásakor látott klinikai és echokardiográfiás státusza változatlan.
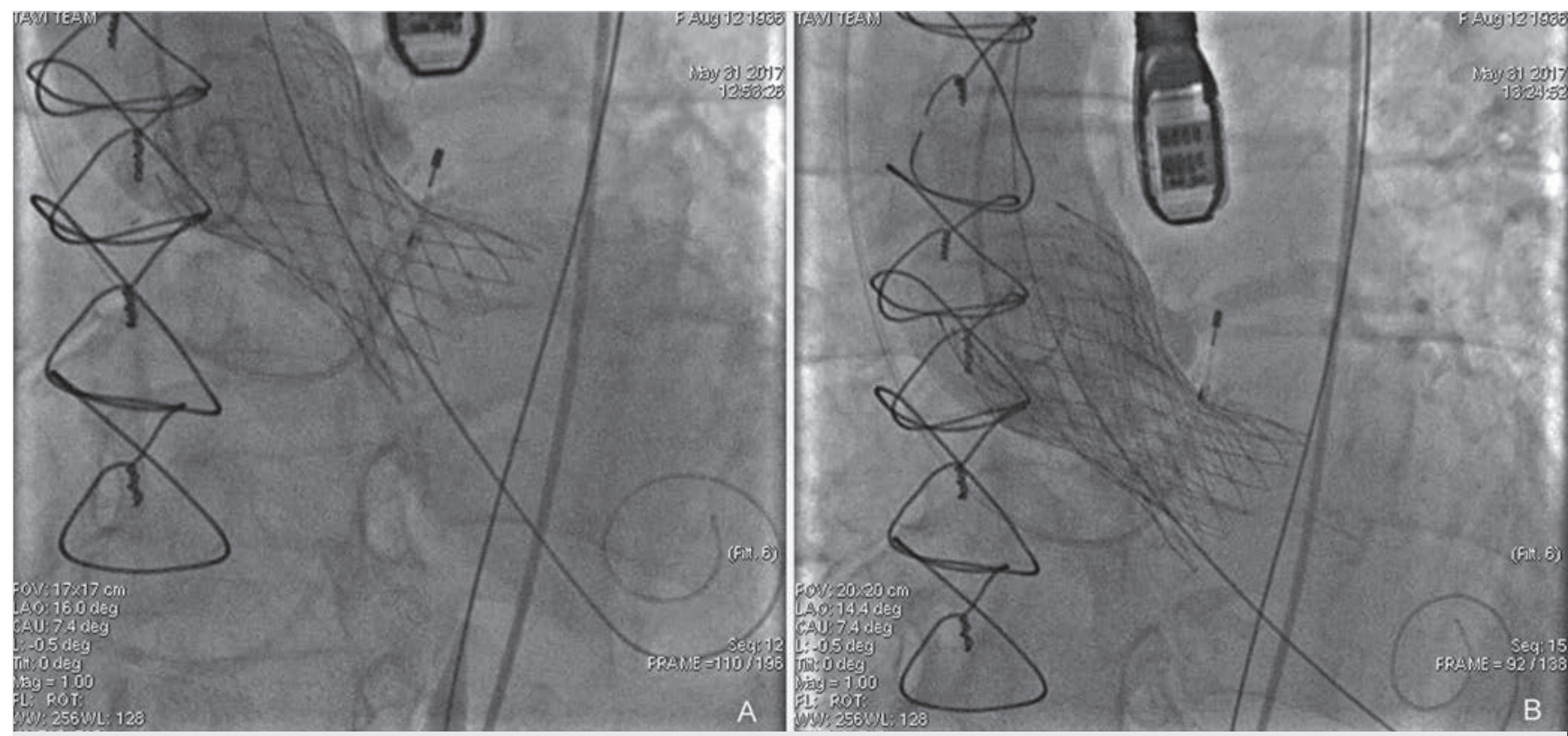

5. ÁBRA. Az első Core Valve Evolute R 29 mm-es billentyű elengedését követően a bal kamra irányába csúszott. A jelentős „upskirt" regurgitáció miatt a beavatkozást végző team egy újabb billentyű beültetése mellett döntött (A). Implantációt követően érdemi regurgitáció már nem látszik (B) 


\section{Következtetések}

A fent ismertetett eset megfelelően példázza az echokardiográfia szerepét mübillentyü-implantáción átesett betegeknél. Felmerülő mübillentyű infektív endocarditis esetén a hagyományos 2D TEE az esetek döntő többségében elegendő a pontos diagnózis megállapításához, azonban az egyre szélesebb körben elérhető 3 dimenziós vizsgálatok szakértő kezekben jelentős segítséget adhatnak bizonytalan esetekben. Ezen felül az utóbbi évtizedben kibontakozó katéteres billentyübeültetések, azon belül is a valve-in-valve esetek kapcsán szerepe kifejezetten kiemelkedő, mivel ilyenkor hiányzik a nyitott szívmütétek kapcsán meglévő vizuális és taktilis megerősítés a felmerülő endocarditisekben. Emellett, habár a jelenlegi tapasztalok TAVI-val kap- csolatban döntően az aortabillentyü-stenosis eseteire korlátozódnak, jelentős aortabillentyü-regurgitáció esetén megfelelő indikáció mellett érdemes gondolni rá.

\section{Irodalom}

1. Bapat V. Technical pitfalls and tips for the valve-in-valve procedure. Ann Cardiothorac Surg 2017; 6(5): 541-552. doi: 10.21037/ acs.2017.09.13

2. Bapat V, Attia R, Redwood S, et al. Use of transcatheter heart valves for a valve-in-valve implantation in patients with degenerated aortic bioprosthesis: technical considerations and results. J Thorac Cardiovasc Surg 2012; 144(6): 1372-80. doi: 10.1016/j.jtcvs.2012.07.104

3. Falk V, Baumgartner H, Bax JJ, et al. ESC Scientific Document Group. ESC/EACTS Guidelines for the management of valvular heart disease. Eur J Cardiothorac Surg 2017; 52(4): 616-664. doi: 10.1093/eurheartj/ehx391

\title{
Az MKT 2018. évi Tudományos Kongresszusa
}

\author{
2018. május 10-12., Balatonfüred \\ Hotel Füred Spa \& Conference \\ 8230 Balatonfüred, Széchenyi István u. 20.
}

\section{Flamingó Wellness és Konferencia Hotel} 8230 Balatonfüred, Széchenyi István u. 16.

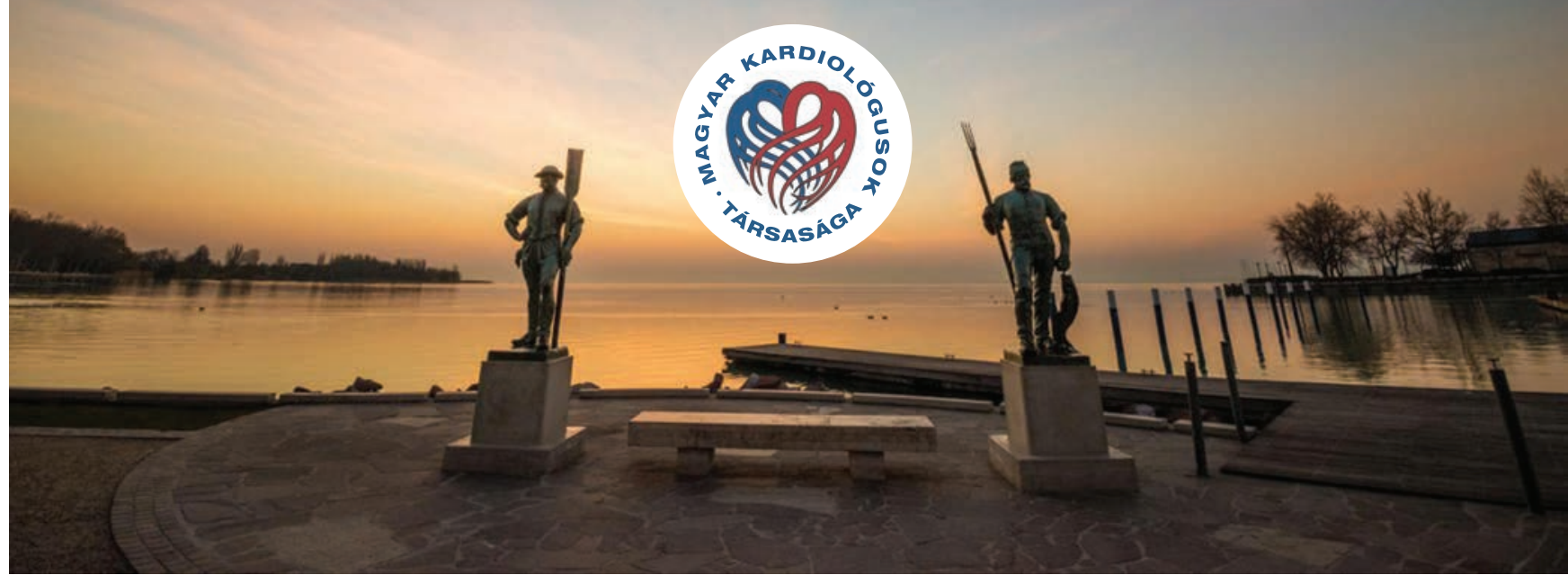

